\title{
Kualitas Nutrisi Hijauan Indigofera zollingeriana yang Diberi Pupuk Hayati Fungi Mikoriza Arbuskula
}

\author{
Suharlina ${ }^{1}$ dan Imam Sanusi ${ }^{2}$ \\ ${ }^{1,2}$ Sekolah tinggi Pertanian Kutai Timur, Jl. Soekarno Hatta No. 1 Sangatta Utara, Kutai \\ Timur, Kalimantan Timur \\ 1Email: suharlina@stiperkutim.ac.id
}

\begin{abstract}
The post-coal mining land has great potenstial to be utilized as forages planting area. This study was conducted to evaluate the effect of arbuscular mycorrhizal fungi (AMF) on the nutritional quality of Indigofera zollingeriana planted which as planted in post-coal mining land. There were 40 Indigofera zollingeriana plants maintained in a poly bag containing $8 \mathrm{~kg}$ of post-mining soil as originally from PT Indexim Coalindo. This study was designed with completely randomized design of 5 treatments, consist of $0,5,10,15$, and $20 \mathrm{~g}$ of $A M F$, respectively. The variables observed were nutritional composition, calcium $(\mathrm{Ca})$, phosphor $(P)$, in vitro dry matter digestibility (IVDMD), in vitro organic matter digestibility (IVOMD), total volatile fatty acids (VFA), and ammonia $\left(\mathrm{NH}_{3}\right)$. The result showed that the crude protein, calcium, and phosphorus content of forage added $15 \mathrm{~g}$ of AMF was higher $(P<0,05)$ than other treatments. The crude fiber content of forage which was added 15 and $20 \mathrm{~g}$ of AMF was lower $(P<0.05)$ than without $A M F$, while nitrogen free extract material content of forage added 15 and $20 \mathrm{~g}$ of $A M F$ was higher $(P<0.05)$ than to others. The IVDMD and IVOMD values, VFA and $\mathrm{NH}_{3}$ concentrations of forage added $15 \mathrm{~g}$ of AMF was higher $(P<0.05)$ than others. The conclution of the study was the nutritional composition and in vitro nutritonal quality forage of Indigofera zollingeriana which was planted in post-mining coal soils by the addition of $15 \mathrm{~g}$ of AMF showed the best results compared to other doses.
\end{abstract}

Keywords: Arbuscular Mycorrhizal Fungi, Indigofera zollingeriana, In vitro, Nutritional quality, Post-mining land

\begin{abstract}
ABSTRAK
Lahan bekas penambangan batu bara memiliki potensi besar untuk dimanfaatkan sebagai lahan penanaman hijauan pakan. Penelitian dilakukan untuk mengevaluasi pengaruh pemberian fungi mikoriza arbuskula (FMA) terhadap kualitas nutrisi hijauan Indigofera zollingeriana yang ditanam di lahan pasca tambang batu bara. Tanaman Indigofera zollingeriana yang digunakan sebanyak 40 tanaman dipelihara di dalam polybag yang berisi $8 \mathrm{~kg}$ media tanam tanah pasca tambang batu bara dari PT Indexim Coalindo. Penelitian didesain dengan rancangan acak lengkap (RAL) 5 perlakuan yaitu inokulasi $0,5,10,15$, dan $20 \mathrm{~g}$ FMA per polybag. Peubah yang diamati adalah komposisi nutrisi, mineral kalsium (Ca), dan fosfor $(\mathrm{P})$, koefisien cerna bahan kering (KCBK), koefisien cerna bahan organik (KCBO), volatil fatty acids (VFA) total dan amonia $\left(\mathrm{NH}_{3}\right)$. Hasil penelitian menunjukkan bahwa kandungan protein kasar, kalsium, dan fosfor hijauan yang diberi $15 \mathrm{~g}$ FMA lebih tinggi $(P<0,05)$ dibandingkan perlakuan lainnya. Kandungan serat kasar hijauan yang diberi 15 dan $20 \mathrm{~g}$ FMA lebih rendah $(\mathrm{P}<0,05)$ dibandingkan tanpa FMA. Kandungan bahan ekstrak tanpa nitrogen hijauan yang diberi 15 dan $20 \mathrm{~g}$ FMA lebih tinggi $(P<0,05)$ dibandingkan perlakuan lainnya. Nilai $K C B K, K C B O$, konsentrasi VFA, dan $\mathrm{NH}_{3}$ hijauan diberi $15 \mathrm{~g}$ FMA lebih tinggi $(\mathrm{P}<0,05)$ dibandingkan perlakuan lainnya. Kesimpulan penelitian adalah kandungan nutrisi dan kualitas kecernaan in vitro hijauan Indigofera zollingeriana ditanam di tanah pasca tambang batu bara dengan pupuk FMA dengan dosis $15 \mathrm{~g}$ menunjukkan hasil terbaik dibandingkan dosis lainnya.
\end{abstract}

Kata kunci: Fungi Mikoriza Arbuskula, Indigofera zollingeriana, In vitro, Kualitas nutrisi, Lahan pasca tambang 


\section{Pendahuluan}

Hijauan merupakan faktor utama yang mempengaruhi perkembangan ruminansia. Hijauan pakan seperti rumput sebagai sumber energi dan serat untuk ruminansia. Penyediaan hijauan yang berkualitas dan berkesinambungan merupakan suatu masalah spesifik di Indonesia. Produktivitas hijauan pakan yang rendah baik dari segi kualitas, kuantitas, dan kontinuitas disebabkan karena lahan yang digunakan untuk tanaman pakan adalah tanah marginal dan terdegradasi. Peningkatan kualitas dan produktivitas hijauan memerlukan pupuk yang merupakan nutrisi bagi tanaman. Manajemen pemberian pupuk sangat penting karena menentukan produksi, kualitas, dan kemampuan tumbuh kembali (regrowth) tanaman tersebut untuk menyediakan hijauan sebagai pakan yang berkualitas tinggi secara berkesinambungan.

Lahan pasca pertambangan batubara merupakan tanah marginal yang dapat dimanfaatkan sebagai lahan tanaman pakan, namun memiliki daya dukung yang rendah terhadap produktivitas hijauan pakan ternak. Pupuk hayati seperti fungi mikoriza arbuskula (FMA) bisa digunakan untuk mengatasi masalah pada tanah marginal dan lahan pasca penambangan batu bara. Lahan pasca penambangan batubara memiliki potensi besar untuk dimanfaatkan sebagai lahan penanaman hijauan pakan terutama leguminosa pohon. Legum dapat digunakan sebagai penutup tanah (Hassen et. al., 2007; Supriadi et al., 2013) dan pencegah erosi lahan bekas penambangan batubara (Suharlina, 2012).

Leguminosa pohon berpotensi menyediakan pakan berkualitas sepanjang tahun. Leguminosa yang berpotensi tumbuh di daerah marginal adalah Indigofera zollingeriana. Indigofera zollingeriana memiliki pertumbuhan yang cepat ada interfal defoliasi 60 hari dengan produksi hijauan mencapai 51 ton bahan kering ha ${ }^{-1}$ tahun $^{-1}$ (Abdullah \& Suharlina, 2010). Indigofera zollingeriana sangat adaptif terhadap tingkat kesuburan rendah, mudah dipelihara dan murah, dan memiliki potensi produksi biji sepanjang musim (Abdullah, 2010).

Informasi mengenai besarnya produksi dan kualitas hijauan leguminosa Indigofera zollingeriana di tanah pasca tambang batubara masih terbatas, sehingga perlu dilakukan penelitian mengenai kualitas nutrisi hijauan I. zollingeriana di tanah pasca penambangan batubara menggunakan fungi mikoriza arbuskula sebagai upaya penyediaan hijauan berkualitas untuk ruminansia. Tujuan penelitian adalah mengevaluasi pengaruh pemberian fungi mikoriza arbuskula (FMA) terhadap kualitas nutrisi hijauan Indigofera zollingeriana.

\section{Materi dan Metode}

Penelitian kandungan dan kualitas nutrisi hijauan dilakukan bulan Juli-Agustus 2019. Penelitian didahului dengan pemanenan hijauan Indigofera zollingeriana yang telah ditanam di greenhouse Laboratorium Teknik Pertanian Sekolah Tinggi Pertanian (STIPER) 
Kutai Timur pada dua bulan sebelumnya. Tanaman dipelihara di dalam polibag yang berisi $8 \mathrm{~kg}$ media tanam berasal dari tanah pasca tambang batu bara. Tanah pasca tambang diperoleh dari lahan pasca tambang PT Indexim Coalindo, Kecamatan Kaliorang Kabupaten Kutai Timur. Desain penelitian menggunakan rancangan acak lengkap (RAL) dengan 5 perlakuan antara lain inokulasi $0 \mathrm{~g}$ FMA (tanpa inokulasi FMA, kontrol), inokulasi $5,10,15$, dan $20 \mathrm{~g}$ per polybag. Masing-masing perlakuan menggunakan empat ulangan. Setiap ulangan menggunakan 2 tanaman sehingga jumlah tanaman sebanyak 40 tanaman. Sebelum perlakuan, tanah pasca tambang diberi pupuk kandang dengan dosis 35 ton/ha. Materi yang digunakan dalam penelitian ini adalah bagian tajuk Indigofera zollingeriana yang yang telah dipanen umur 60 hari setelah tanam. Peubah yang diamati adalah komposisi nutrisi, mineral kalsium (Ca), dan fosfor $(\mathrm{P})$, koefisien cerna bahan kering (KCBK), koefisien cerna bahan organik (KCBO), volatil fatty acids (VFA) total dan amonia $\left(\mathrm{NH}_{3}\right)$. Analisis kandungan nutrisi, kandungan mineral $\mathrm{Ca}$ dan $\mathrm{P}$ hijauan dan kecernaan in vitro (KCBK dan KCBO) diuji di Laboratorium IImu dan Teknologi Pakan Institut Pertanian Bogor (IPB). Komposisi nutrisi diukur menggunakan metode proksimat (AOAC 1995). Pengukuran konsentrasi $\mathrm{Ca}$ dan $\mathrm{P}$ menggunakan metode pengabuan basah (Reitz et al. 1960) dilanjutkan dengan pembacaan konsentrasi Ca menggunakan AAS dan pembacaan konsentrasi P dengan spektrofotometer. Pengukuran koefisien cerna bahan kering (KCBK), koefisien cerna bahan organik (KCBO) secara in vitro menggunakan metode Tilley \& Terry (1963). Kandungan VFA total diukur menggunakan metode steam destilation method, sedangkan kadar amonia $\left(\mathrm{NH}_{3}\right)$ diukur menggunakan metode micro diffusion conway (Department of Dairy Science, 1966).

Rumus perdihitungan sebagai berikut:

$$
\begin{aligned}
& \operatorname{KCBK}(\%)=\frac{\text { BK Sampel }_{(g)}-\text { BK Residu }_{(g)}-\text { BK Blanko }_{(g)}}{\text { BK Sampel }_{(g)}} \times 100 \% \\
& \mathrm{KCBO}(\%)=\frac{\text { BO Sampel }_{(\mathrm{g})}-\text { BO Residu }_{(\mathrm{g})}-\text { BO Blanko }_{(\mathrm{g})}}{\text { BO Sampel }_{(\mathrm{g})}} \times 100 \% \\
& V F A_{\text {total }}=(a-b) \times \mathrm{N} \mathrm{HCl} \times \frac{1000}{5} \\
& \mathrm{NH}_{3}=\left[\left(\mathrm{V}_{\mathrm{s}}-\mathrm{V}_{0}\right) \times \mathrm{N} \mathrm{H}_{2} \mathrm{SO}_{4} \times 1000\right] \\
& \text { Keterangan: } \quad \mathrm{KCBK}=\text { Koefisien Cerna Bahan Kering; } \\
& \mathrm{KCBO}=\text { Koefisien Cerna Bahan Organik; } \\
& \mathrm{BK}=\text { Bahan Kering; } \\
& \mathrm{BO}=\text { Bahan Organik; } \\
& \text { VFA = Volatil Fatty Acids (Mmol); } \\
& \mathrm{NH}_{3} \quad=\text { Amonia }(\mathrm{Mmol}) \text {; } \\
& \mathrm{a}=\text { volume titran } \mathrm{HCl} \text { untuk blanko }(\mathrm{ml}) \text {; } \\
& \mathrm{b}=\text { volume titran sampel }(\mathrm{ml}) \text {; } \\
& \text { Vs = volume titran sampel; }
\end{aligned}
$$


Jurnal Pertanian Terpadu 8(1): 52-61, Juni 2020 ISSN 2549-7383 (online)

ISSN 2354-7251 (print)

$\mathrm{V}_{\mathrm{O}}=$ adalah volume titran blanko http://ojs.stiperkutim.ac.id/index.php/jpt https://doi.org/10.36084/jpt..v8i1.219

Data dianalisis menggunakan sidik ragam, jika terdapat perbedaan dilakukan uji lanjut Least Significance Different (LSD).

\section{Hasil dan Pembahasan}

\section{Komposisi Nutrisi}

Komposisi nutrisi hijauan Indigofera zollingeriana dalam penelitian ini diperlihatkan pada Tabel 1. Kadar abu merupakan komponen mineral atau bahan anorganik yang terdapat bahan pakan. Kadar abu dalam penelitian ini berkisar 8,09-8,96\%, menurun seiring dengan peningkatan taraf pemberian FMA pada I. zollingeriana. Penurunan kadar abu mengindikasikan terdapat peningkatan kadar bahan organik pada I. zollingeriana dalam penelitian ini. Menurut Barokah et al., (2017) penurunan kandungan abu (bahan anorganik) dalam bahan pakan sangat diharapkan, karena akan meningkatkan kandungan bahan organik seperti protein, lemak, karbohidrat, dan vitamin.

Tabel 1. Komposisi nutrisi hijauan Indigofera zollingeriana yang diberi pupuk FMA di tanah pasca tambang batubara

\begin{tabular}{|c|c|c|c|c|c|}
\hline \multirow{2}{*}{$\begin{array}{l}\text { Kandungan Nutrisi } \\
(100 \% \mathrm{BK})\end{array}$} & $F_{0}$ & $F_{5}$ & $F_{10}$ & $F_{15}$ & $\mathbf{F}_{20}$ \\
\hline & \multicolumn{5}{|c|}{ Makro nutrisi } \\
\hline Kadar Abu & $8,96 \pm 0,29^{a}$ & $8,64 \pm 0,61^{a b}$ & $8,31 \pm 0,21 b c$ & $8,51 \pm 0,14^{a b c}$ & $8,09 \pm 0,05^{c}$ \\
\hline Lemak Kasar & $2,24 \pm 0,03$ & $2,42 \pm 0,39$ & $2,2 \pm 0,53$ & $1,64 \pm 0,31$ & $2,74 \pm 0,97$ \\
\hline Protein Kasar & $23,09 \pm 0,38^{e}$ & $23,96 \pm 0,20^{d}$ & $25,18 \pm 0,28^{c}$ & $28,66 \pm 0,22^{a}$ & $27,24 \pm 0,57^{b}$ \\
\hline Serat Kasar & $16,69 \pm 0,96^{a}$ & $15,87 \pm 0,96^{a b}$ & $15,29 \pm 0,51^{b}$ & $13,90 \pm 0,66^{c}$ & $14,74 \pm 0,49 \mathrm{bc}$ \\
\hline BETN & $49,02 \pm 0,59^{a}$ & $49,11 \pm 0,82^{a}$ & $49,00 \pm 0,86^{a}$ & $47,29 \pm 0,47^{b}$ & $47,19 \pm 1,42^{b}$ \\
\hline Kalsium (Ca) & $0,37 \pm 0,02^{d}$ & $0,43 \pm 0,01^{c}$ & $0,51 \pm 0,02^{b}$ & $0,57 \pm 0,02^{a}$ & $0,53 \pm 0,03^{b}$ \\
\hline Fosfor $(\mathrm{P})$ & $0,13 \pm 0,01^{c}$ & $0,14 \pm 0,02^{c}$ & $0,20 \pm 0,05^{b}$ & $0,26 \pm 0,00^{a}$ & $0,20 \pm 0,00^{b}$ \\
\hline
\end{tabular}

a,b) superskrip yang berbeda pada baris yang sama menunjukkan perbedaan nyata $(\mathrm{P}<0,05) . \mathrm{F}_{0}=\operatorname{tanpa} F M A$; $F_{5}=5 \mathrm{~g} F M A ; F_{10}=10 \mathrm{~g} F M A ; F_{15}=15 \mathrm{~g}$ FMA; $F_{20}=20 \mathrm{~g}$ FMA; BETN = Bahan ekstrak tanpa nitrogen

Kandungan lemak kasar hijauan Indigofera yang ditanam pada tanah pasca tambang berkisar 1,64-2,74\%. Penambahan pupuk FMA pada hijauan Indigofera yang ditanam pada lahan pasca tambang tidak memperlihatkan perbedaan nyata terhadap kandungan lemak kasar. Nilai lemak kasar hijauan I. zollingeriana ini lebih rendah dibandingkan hasil Abdullah (2010) sebesar 2,63\%. Nilai kandungan nilai lemak kasar ini setara dengan lemak kasar hijauan leguminosa lainnya yaitu Calliandra calothyrsus 1,512,84\% (Abqoriyah et al., 2015). Kandungan lemak kasar I. zollingeriana yang rendah tergolong aman untuk ruminansia. Kandungan lemak kasar pakan di bawah 6\% tidak memberikan efek negatif terhadap populasi dan aktivitas mikroba dalam rumen sapi potong (Suharti et al., 2015). Kandungan lemak kasar yang tinggi pada pakan dapat menghambat aktivitas dan menurunkan populasi mikroba rumen, serta menyebabkan toksik bagi bakteri pencerna serat. 
Indigofera zollingeriana yang diberi pupuk FMA memperlihatkan kandungan protein lebih $(\mathrm{P}<0,05)$ baik dibandingkan yang tidak diberi pupuk FMA. Kandungan protein paling tinggi sebesar 28,66\% dicapai oleh tanaman yang diberi pupuk sebanyak $15 \mathrm{~g}\left(\mathrm{~F}_{15}\right)$ disusul oleh tanaman yang diberi pupuk $20\left(F_{20}\right), 10\left(F_{10}\right)$, dan $5\left(F_{5}\right)$ g FMA (Tabel 1). Kandungan protein Indigofera dalam penelitian ini sesuai dengan penelitian Suharlina et al. (2019), yaitu kandungan protein I. zollingeriana berkisar 24-31\% jika dengan penambahan pupuk organik. Akumulasi bahan organik seperti protein pada hijauan $I$. zollingeriana mengindikasikan bahwa terjadi peningkatan penyerapan unsur hara oleh akar tanaman. Pemberian pupuk FMA berperan dalam peningkatkan penyerapan unsur hara dengan cara berasosiasi dengan akar tanaman. Menurut Sieverding (1991) akar tanaman yang terinfeksi FMA memiliki tingkat metabolisme 2-4 kali lebih tinggi dibandingkan yang tidak terinfeksi oleh mikoriza. Hifa mikoriza arbuskula membantu menembus partikel tanah pasca tambang yang cenderung liat dan tidak dapat ditembus oleh akar untuk menyerap air dan unsur hara. Akar tanaman yang terinfeksi mikoriza arbuskula memiliki luas penyerapan unsur hara lebih besar dan mampu meningkatkan penyerapan unsur hara dan air sehingga kandungan nutrisi khususnya protein dalam tanaman juga meningkat. Kekuatan penyerapan unsur hara dan air dari tanaman bermikoriza lebih tinggi dibandingkan yang tidak bermikoriza karena hifa FMA meluas di dalam tanah dan menyerap ion-ion yang terbebas dari penguraian mineral oleh mikroorganisme lain dan mentranslokasinya melalui misellia fungi ke dalam perakaran tanaman inang, sehingga peningkatan penyerapan unsur hara tanaman melalui asosiasinya dengan FMA sebagian besar disebabkan oleh perluasan sistem penyerapan akar dengan adanya misellia dari FMA (Pulungan, 2013).

Kandungan serat kasar Indigofera yang diberi pupuk FMA pada tanah pasca tambang batubara, memperlihatkan perbedaan nyata $(P<0,05)$. Kandungan serat kasar tanaman yang diberi pupuk FMA $15 \mathrm{~g}$ memperlihatkan nilai yang paling rendah $(P<0,05)$ dibandingkan tanpa pupuk FMA. Kandungan serat kasar dalam penelitian berkisar 13,9$16,69 \%$ selaras dengan hasil pengukuran Abdullah dan Suharlina (2010) yaitu kandungan serat kasar Indigofera berkisar 10,97-15,02\% dengan umur defoliasi tanaman 38-88 hari. Hal tersebut mengindikasikan bahwa dengan penambahan pupuk FMA, sel tanaman aktif tumbuh karena ketersediaan unsur hara dari dalam tanah lebih banyak tersedia. Tanaman yang aktif tumbuh akan banyak menghasilkan biomassa muda yang masih banyak mengandung bahan organik mudah tercerna, diantaranya protein dan karbohidrat non serat. Tanaman yang tidak diberikan FMA, pertumbuhannya terganggu karena ketersediaan unsur hara terbatas.

Bahan ekstrak tanpa nitrogen (BETN) merupakan komponen karbohidrat yang mudah larut seperti pati dan glukosa. Nilai BETN bahan pakan tergantung pada nilai 
ISSN 2354-7251 (print)

komposisi nutrisi lainnya seperti abu, protein kasar, serat kasar, dan lemak kasar. Hal tersebut karena BETN didapatkan dari hasil pengurangan bahan kering dengan komponen organik (protein kasar, serat kasar, dan lemak kasar) dan anorganik (abu) (Pond et al., 2004). Nilai BETN hijauan pada perlakuan $F_{15}$ dan $F_{20}$ lebih rendah dibandingkan dengan hijauan dengan perlakuan $\mathrm{F}_{0}, \mathrm{~F}_{5}$, dan $\mathrm{F}_{10}$ (Tabel2). Nilai BETN yang rendah pada pelakuan $F_{15}$ dan $F_{20}$ karena proporsi komponen organik yang mengandung nitrogen pada perlakuan $\mathrm{F}_{15}$ dan $\mathrm{F}_{20}$ lebih tinggi dibandingkan perlakuan lainnya.

Mineral yang diukur dalam penelitian ini adalah kalsium (Ca) dan Fosfor (P). Terdapat perbedaan $(P<0,05)$ mineral $C a$ dan $P$ antara tanaman yang mendapatkan pupuk FMA dibandingkan tanpa pemupukan FMA. Hijauan yang mengandung kalsium dan fosfor paling tinggi adalah hijauan yang diberi pupuk FMA $15 \mathrm{~g}$ (Tabel 1) dengan nilai Ca dan $\mathrm{P}$ masing-masing 0,57 dan $0,26 \%$. Nilai Ca pada penelitian ini lebih rendah dibandingkan dengan hasil Suharlina et al. (2019) yaitu pada kisaran 0,65-0,73\%, yang ditanam pada media tanah dengan $\mathrm{pH}$ normal. Hal tersebut kemungkinan dikarenakan perbedaan media tanah yang digunakan. Media tanah yang digunakan pada penelitian ini adalah tanah pasca tambang batubara dengan kisaran $\mathrm{pH}$ 5-6. Pada kondisi $\mathrm{pH}$ demikian Ca menjadi kurang tersedia untuk tanaman.

Nilai P pada penelitian ini lebih tinggi dibandingkan hasil Suharlina et al. (2019) yang menyebutkan $0,12-0,16 \%$. Nilai $P$ yang lebih tinggi disebabkan adanya peran FMA. FMA meningkatkan serapan $\mathrm{P}$ tanaman I. zollingeriana. FMA membutuhkan energi yang pada masa pertumbuhan awalnya diambil dari tumbuhan inangnya, akan tetapi pada masa pertumbuhannya juga FMA menyerap unsur hara $P$ melalui hifa eksternalnya dan dipertukarkan dengan energi dari tanaman dalam bentuk gula sederhana. Unsur hara $P$ digunakan oleh tanaman untuk membentuk adenosine triphosphate (ATP) dan nikotinamid adenin dinukleotida fosfat (NADPH) dalam proses fotosintesis. Pembentukan ATP dan NADPH merupakan mekanisme penyimpanan energi dari cahaya matahari diubah menjadi energi kimia pada reaksi terang di dalam grana. Adenosine triphosphate (ATP) dan NADPH diperlukan untuk mereduksi $\mathrm{CO}_{2}$ pada reaksi gelap yang berlangsung di dalam stroma yang menghasilkan karbohidrat (Song, 2012). Banyaknya kandungan P dalam tanaman dapat meningkatkan kemampuan tanaman untuk menghasilkan ATP dan NADPH sehingga kemampuan mereduksi $\mathrm{CO}_{2}$ juga meningkat, akibatnya hasil fotosintesis juga meningkat dan dapat memicu pertumbuhan tanaman.

\section{Kualitas Nutrisi}

Nilai KCBK dan KCBO merupakan penentu utama kualitas pakan hijauan. Hijauan merupakan bahan pakan yang khas dan tantangan terkini terhadap kemampuan ternak untuk mencerna dan menyerap nutrisi (Mertens, 2007). Koefisien cerna pakan hijauan yang 
tinggi menyebabkan semakin tinggi nutrisi pakan yang dapat digunakan untuk memenuhi kebutuhan nutrisi tubuh ternak. Koefisien cerna hijauan juga ditentukan oleh komposisi serat yang terdapat dalam jaringan tanaman. Koefisien cerna bahan kering, dan bahan organik diperlihatkan pada Tabel 2.

Tabel 2. Pengaruh pemberian pupuk FMA terhadap kualitas kecernaan nutrisi Indigofera zollingeriana secara in vitro

\begin{tabular}{lccccc}
\hline \multirow{2}{*}{ Kualitas Nutrisi } & $\mathbf{F}_{\mathbf{0}}$ & $\mathbf{F}_{\mathbf{5}}$ & $\mathbf{F}_{\mathbf{1 0}}$ & $\mathbf{F}_{\mathbf{1 5}}$ & $\mathbf{F}_{\mathbf{2 0}}$ \\
\cline { 2 - 6 } & \multicolumn{5}{c}{ Kualitas in vitro } \\
\hline KCBK (\%) & $69,96 \pm 0,66^{\mathrm{e}}$ & $71,39 \pm 0,40^{\mathrm{d}}$ & $72,52 \pm 0,52^{\mathrm{c}}$ & $76,91 \pm 0,69^{\mathrm{a}}$ & $74,01 \pm 0,65^{\mathrm{b}}$ \\
KCBO (\%) & $68,93 \pm 0,74^{\mathrm{d}}$ & $70,23 \pm 0,53^{\mathrm{c}}$ & $71,14 \pm 0,57^{\mathrm{c}}$ & $76,14 \pm 0,65^{\mathrm{a}}$ & $72,43 \pm 0,57^{\mathrm{b}}$ \\
VFA (Mmol) & $63,85 \pm 5,85^{\mathrm{d}}$ & $82,19 \pm 4,94^{\mathrm{c}}$ & $89,66 \pm 0,40^{\mathrm{c}}$ & $121,72 \pm 11,02^{\mathrm{a}}$ & $103,31 \pm 9,13^{\mathrm{b}}$ \\
$\mathrm{NH}_{3}$ (Mmol) & $6,48 \pm 0,61^{\mathrm{d}}$ & $7,62 \pm 0,31^{\mathrm{c}}$ & $8,50 \pm 0,30^{\mathrm{c}}$ & $11,93 \pm 0,86^{\mathrm{a}}$ & $9,69 \pm 0,91^{\mathrm{b}}$ \\
\hline
\end{tabular}

$\mathrm{a}, \mathrm{b})$ superskrip yang berbeda pada baris yang sama menunjukkan perbedaan nyata $(\mathrm{P}<0,05)$. $\mathrm{F}_{0}=\operatorname{tanpa} \mathrm{FMA}$; $F_{5}=5 \mathrm{~g} F M A ; F_{10}=10 \mathrm{~g} F M A ; F_{15}=15 \mathrm{~g} F M A ; F_{20}=20 \mathrm{~g}$ FMA;

Koefisien cerna in vitro bahan kering (KCBK) pada penelitian ini berkisar 69,96 76,91\% (Tabel 2). Hal tersebut setara dengan hasil penelitian Suharlina et al. (2019) sebesar 68,21-73,15\% pada hijauan Indigofera yang dipupuk menggunakan limbah industri penyedap masakan. Nilai KCBK hijauan yang diberi pupuk FMA berbeda nyata $(P<0,05)$ dibandingkan hijauan dari tanaman yang tidak dipupuk FMA. Nilai KCBK tertinggi dalam penelitian ini terlihat pada tanaman Indigofera yang diberi pupuk $15 \mathrm{~g}$ FMA (perlakuan $F_{15}$ ). Penambahan FMA dapat meningkatkan nilai $\mathrm{KCBK}$, hal tersebut dikarenakan peningkatan bahan organik atau kandungan nutrisi hijauan yang juga meningkat. Nilai KCBK dalam penelitian ini berbanding terbalik dengan kandungan serat kasar. Peningkatan kandungan serat kasar pada hijauan $I$. zollingeriana yang diberi pupuk FMA dosis rendah menurunkan nilai KCBK.

Nilai koefisien cerna in vitro bahan organik (KCBO) pada penelitian ini memiliki pola yang sama dengan nilai KCBK. Nilai KCBO pada penelitian ini berkisar 68,93-76,14\% (Tabel 2), setara dengan hasil penelitian Suharlina et al. (2019) sebesar 65,33-70,64\% pada hijauan Indigofera yang dipupuk menggunakan limbah industri penyedap masakan. Nilai KCBO hjauan yang diberi pupuk FMA berbeda nyata $(\mathrm{P}<0,05)$ dibandingkan hijauan dari tanaman yang tidak dipupuk FMA. Nilai KCBO tertinggi dalam penelitian ini terlihat pada tanaman Indigofera yang diberi pupuk $15 \mathrm{~g}$ FMA. Peningkatan nilai KCBO pada penelitian ini memiliki pola yang sama dengan nilai KCBK. Hal tersebut karena bahan organik merupakan bagian dari bahan kering, dan kandungan bahan organik hijauan yang juga meningkat sering dengan bertambahnya dosis FMA.

Degradasi karbohidrat di dalam rumen ruminansia menghasilkan VFA yang merupakan sumber energi untuk ternak. Komponen utama VFA adalah asam asetat, asam propionat, asam butirat, dan sejumlah kecil asam valerat. Hijauan yang diberi pupuk FMA $15 \mathrm{~g}$ memperlihatkan konsentrasi VFA paling tinggi, disusul oleh hijauan yang diberi pupuk FMA $20 \mathrm{~g}$ (Tabel 2). Konsentrasi VFA dalam penelitian ini tidak berbanding lurus dengan 
kandungan BETN, yang merupakan karbohidrat paling cepat didegradasi. Perlakuan $\mathrm{F}_{0}, \mathrm{~F}_{5}$, dan $F_{10}$ menghasilkan VFA lebih rendah dibandingkan perlakuan $F_{15}$ dan $F_{20}$ meskipun memiliki BETN lebih tinggi. Konsentrasi VFA erat kaitannya dengan kandungan serat kasar hijauan I. zollingeriana dalam penelitian ini. Konsentrasi VFA meningkat apabila konsentrasi serat kasar hijauan I. zollingeriana menurun. Serat kasar merupakan fraksi yang tidak mudah didegradasi oleh mikroba rumen. Fraksi serat merupakan faktor pembatas dalam degradasi karbohidrat secara fermentasi di dalam sistem rumen ternak ruminansia. Adanya anti nutrisi berupa tannin dan saponin juga mempengaruhi aktivitas mikroba rumen dalam mendegradasi pakan. Tanin dan saponin dapat berfungsi sebagai agen defaunasi yang memproteksi nutrisi dari degradasi mikroba rumen. Hijauan I. zollingeriana mengandung tannin 2,9 g/kg BK dan 2,6 mg/kg BK saponin (Suharlina et. al., 2016).

Proses degradasi protein pakan di dalam rumen menghasilkan amonia $\left(\mathrm{NH}_{3}\right)$. Konsentrasi $\mathrm{NH}_{3}$ akan semakin tinggi apabila jumlah protein pakan yang didegradasi dalam rumen juga tinggi. Konsentrasi $\mathrm{NH}_{3}$ bermanfaat bagi mikroba rumen untuk sintesis tubuhnya. Konsentrasi $\mathrm{NH}_{3}$ dalam penelitian ini berkisar 6,48-11,93 mMol (Tabel 2). Hijauan yang diberi pupuk FMA $15 \mathrm{~g}\left(\mathrm{~F}_{15}\right)$ dapat meningkatkan konsentrasi $\mathrm{NH}_{3}$ sebesar 84,1\% dibandingkan tanpa pupuk FMA. Peningkatan konsentrasi $\mathrm{NH}_{3}$ karena terjadi peningkatan protein pada hijauan akibat pemberian pupuk FMA.

\section{Kesimpulan}

Pemberian pupuk FMA dengan dosis $15 \mathrm{~g}\left(\mathrm{~F}_{15}\right)$ pada hijauan Indigofera zollingeriana yang ditanam di tanah pasca tambang batu bara menunjukkan hasil terbaik terhadap kandungan nutrisi dan kualitas kecernaan in vitro hijauan. Hasil tersebut menunjukkan adanya peningkatan kualitas pakan, namun masih perlu diujikan pada ternak secara in vivo. Meskipun demikian, pemanfaatan pupuk FMA pada budidaya tanaman pasca tambang perlu ditingkatkan, khususnya dalam upaya meningkatan kualitas hijauan pakan ternak ruminansia.

\section{Ucapan Terima Kasih}

Ucapan terima kasih disampaikan kepada Kementerian Riset, Teknologi, dan Pendidikan Tinggi yang telah membiayai penelitian ini melalui program Hibah penelitian dosen pemula berdasarkan surat keputusan nomor 7/E/KPT/2019 dan perjanjian/kontrak nomor 106/KONTRAK/STIPER/VII/2019, dan PT. Indexcim Coalindo yang membantu memfasilitasi media tanam tanah pasca tambang batubara.

\section{Daftar Pustaka}

Abdullah, L. (2010). Herbage production and quality of shrub Indigofera treated by different concentration of foliar fertilizer. Media Peternakan, 33(3), 169. 
Abdullah, L. \& Suharlina. (2010). Herbage Yield and Quality of Two Vegetative Parts of Indigofera at Different Times of First Regrowth Defoliation. Media Peternakan, 33(1), 44.

Abqoriyah, Utomo, R., \& Suwignyo, B. (2015). Produktivitas tanaman kaliandra (Calliandra calothyrsus) sebagai hijauan pakan pada umur pemotongan yang berbeda. Buletin Peternakan, 39(2), 103-108.

AOAC. (1995). Official methods of analysis of AOAC International, 16th edition. Volume 2. 1995. AOAC (Association of Official Analytical Chemists) International; Arlington; USA.

Barokah, Y., Ali, A., \& Erwan, E. (2017). Nutrisi Silase Pelepah Kelapa Sawit Yang Ditambah Biomassa Indigofera (Indigofera zollingeriana). Jurnal IImiah IImu-IImu Peternakan, 20(2), 59-68.

Department of Dairy Science. (1966). General Laboratory Procedures. University of Wisconsin, Madison.

Hassen, A., Rethman, N. F. G., Van Niekerk, W. A., \& Tjelele, T. J. (2007). Influence of season/year and species on chemical composition and in vitro digestibility of five Indigofera accessions. Animal feed science and technology, 136(3-4), 312-322.

Mertens D.R. (2007) Digestibility and intake. In: Barnes R.F., Nelson J.C., Moore K.J. and Collons M. (eds) Forages, The Science of Grassland Agriculture, Vol. II. Blackwell Publishing, Ames, lowa, USA, pp. 487-508.

Pond, W. G., Church, D. B., Pond, K. R., \& Schoknecht, P. A. (2004). Basic animal nutrition and feeding. John Wiley \& Sons.

Pulungan, A. S. S. (2013). Infeksi fungi mikoriza arbuskula pada akar tanaman tebu (Saccharum officinarum L). Jurnal Biosains Unimed, 1(01), 43-46.

Reitz, L. L., Smith, W. H., \& Plumlee, M. P. (1960). Simple, wet oxidation procedure for biological materials. Analytical Chemistry, 32(12), 1728-1728.

Sieverding, E., Friedrichsen, J., \& Suden, W. (1991). Vesicular-arbuscular mycorrhiza management in tropical agrosystems. Sonderpublikation der GTZ (Germany).

Song, A. N. (2012). Evolusi fotosintesis pada tumbuhan. Jurnal IImiah Sains, 12(1), 28-34.

Suharlina, Abdullah, L., \& Lubis, A. D. (2019). Kualitas Nutrisi Hijauan (Indigofera zollingerina) yang Diberi Pupuk Organik Cair Asal Limbah Industri Penyedap Masakan. Jurnal Pertanian Terpadu, 7(1), 28-37.

Suharlina, S., Astuti, D. A., Nahrowi, N., Jayanegara, A., \& Abdullah, L. (2016). In vitro evaluation of concentrate feed containing Indigofera zollingeriana in goat. Journal of Indonesian Tropical Animal Agriculture, 41(4), 196-203.

Suharlina. (2012). Manfaat Indigofera sp. dalam bidang pertanian dan industri. Pastura, 2 (1): 30-33.

Suharti, S., Nasution, A.R., Aliyah, D.N., \& Hidayah, N. (2015). Potensi minyak kanola dan flaxseed terproteksi sabun kalsium untuk mengoptimalkan fermentasi dan mikroba rumen sapi potong secara in vitro. Prosiding Seminar Nasional Masyarakat Biodiversitas Indonesia, 1(1): 89-92.

Supriadi, Suharjo, M., Catur, P., Mulyadi. (2013). Dwifungsi leguminosa sebagai pakan dan rehabilitasi lahan pasca erupsi merapi. Prosiding Seminar nasional Hasil Penelitian Tanaman Aneka Kacang dan Umbi. Malang 22 Mei 2013. Pusat Penelitian dan Pengembangan Tanaman Pangan. Badan Penelitian dan Pengembangan Pertanian, 764-769. 
Jurnal Pertanian Terpadu 8(1): 52-61, Juni 2020

http://ojs.stiperkutim.ac.id/index.php/jpt ISSN 2549-7383 (online)

https://doi.org/10.36084/jpt..v8i1.219

ISSN 2354-7251 (print)

Tilley, J. M. A., \& Terry, R. A. (1963). A two-stage technique for the in vitro digestion of forage crops. Grass and forage science, 18(2), 104-111. 